\title{
DISAIN PENCIPTAAN FILM PAKASIAH BABIOLA
}

\author{
Muhammad Ritzky Saibi, Yusril, Sahrul N \\ PascaSarjana-Institut Seni Indonesia Padangpanjang \\ E-mail : yusril2001@gmail.com, sharief.kirun@gmail.com
}

\begin{abstract}
Abstrak
Menciptakan film fiksi "Pakasiah Biola", berangkat dari beberapa bagian unsur film, dimana film apabila ditinjau dari segi genre dibagi menjadi tiga bagian yaitu film fiksi, film dokumenter dan film experimental. Pilihan terhadap genre fiksi yang pengkarya lakukan disini karena dalam film dengan genre tersebut memiliki ruang yang sangat luas dalam mentransformasikan ide-ide dan ruang untuk merealisasikan pemikiran-pemikiran imajinatif yang pengkarya peroleh ketika menganalisa naskah "Pakasiah Biola" baik secara visual/cinematic ataupun secara naratif.Pada konsep garapan karya film Pakasiah Biola yang akan dibuat, pengkarya menciptakan film berdasarkan pemikiran Bazin terdapat 7 hal yang menjadi elemen struktur film realis, yang meliputi: relative simple strories, real location, real setting unprofessional actors, deep-fosus, longtake, dan minimize editing
\end{abstract}

Kata Kunci: Pakasiah Biola; Film Fiksi; Genre Fiksi.

\begin{abstract}
Minang Creating the fictional film "Pakasiah Biola" departs from several parts of the film's elements, where the film, when viewed from a genre perspective, is divided into three parts, namely fiction films, documentary films, and experimental films. The choice of the fiction genre that the author makes here is because films with that genre have a very wide space in transforming ideas and space to realize the imaginative thoughts that the author gets when analyzing the script "Pakasiah Biola" either visually/cinematically or narratively. In the concept of the work of Pakasiah Biola that will be made, the artist creates a film based on Bazin's thinking, and there are 7 things that become elements of the realist film structure, which include: relatively simple stories, reallocation, real setting unprofessional actors, deepfocus, long-take and minimize editing

Keywords: Pakasiah Violin; Fiction Movies; Fiction Genre.
\end{abstract}

PENDAHULUAN

Babiola ini merupakan istilah yang dipakai oleh masyarakat Pesisir Selatan yang berkonotasi dengan istilah rabab pasisie. Babiola biasa digunakan sebagai sarana hiburan dan sarana mistis. Pada sarana hiburan, Babiola memiliki fungsi sebagai pengiring musik untuk menghibur masyarakat yang datang menontonya, sedangkan pada sarana mistis Babiola dijadikan untuk kepentingan individu seperti menggunakan ilmu pakasih (sebuah kepercayaan yang dapat meningkatkan daya tarik seseorang terhadap orang lain) dan pitunang (pemanis atau ilmu pelet melalui bunyian).

Babiola merupakan seni tradisi yang berkembang di tengah masyarakat di daerah Kabupaten Pesisir Selatan. Menurut cerita yang pernah dipaparkan bahwasanya Munas (pemain biola) yang dituduh terlibat dengan PKI. Beliau ditangkap dan dimasukan ke dalam penjara oleh pemerintah saat itu. Ketika akan di eksekusi mati beliau memohon pada komandan aparat keamanan untuk diijinkan memainkan biolanya sebagai 
permintaan terakhir sebelum menjalani hukuman. Permintaan tersebut dikabulkan oleh komandan, dan beliau memainkan Babiola untuk menarik rasa suka istri komandan keamanan yang tinggal tidak jauh dari sel tahanan. Pada saat akan dieksekusi mati dengan senapan, istri komandan datang dan menghalangi eksekusi tersebut. Istri komandan mengatakan, "kalau ingin membunuh dia (tukang rabab tersebut) bunuh saya sekalian". Eksekusi batal dilakukan, tukang rabab tersebut kemudian dibebaskan.

Dari fenomena tersebut lahirlah karya film dengan judul Pakasiah Babiola. Pengkarya menciptakan film fiksi Pakasiah Biola ini memperhitungkan aspek kehidupan yang pernah terjadi dan didapat dalam sebuah cerita, adapun pesan yang ingin disampaikan kepada penonton dan seniman Babiola tentang kehidupan bapak Munas selaku tokoh yang selamat pada saat kejadian yang mengerikan itu. Film yang dihadirkan bersifat fiksi yang bersumber dari mitos.

\section{STUDI LITERATUR}

Film Setan Jawa merupakan sebuah film yang di sutradarai oleh Garin Nugroho, produksi pada tahun 2016. Dimana seorang pemuda yang bernama Setio yang berasal dari desa miskin yang jatuh cinta kepada Asih yang berasal dari keluarga bangsawan. Dimana Setio mencoba untuk melamar Asih yang berujung pada penolakan kasar dari keluarga Asih. Berawal dari penolakan Asih kepada Setio, Setio memilih jalan pintas untuk berupa pesugihan untuk memperkaya diri sehingga lamarannya dapat diterima.

Film Sang Penari merupakan film yang sutradarai oleh Ifa Isfansyah, produksi pada tahun 2003. Kesamaan setting zaman, kesamaan cerita sama-sama memperlihatkan sisi lain kehidupan seniman pada masa pergolakan politik dan militer di Indonesia. Sama-sama menggunakan pendekatan realisme. Perbedaannya terletak pada pemilihan pemain dalam film tersebut. Untuk mencapai realis Sang Penari didukung oleh aktor-aktor terkenal, sedangkan film Pakasiah Biola diperankan oleh aktor amatir.

Puisi tak Terkuburkan adalah film realisme yang diusung Garin Nugroho muncul hampir dalam keseluruhan film garapannya. Film Puisi Tak Terkuburkan ini diproduksi pada tahun 2000 yang menggunakan pendekatan dokumenter telah membawa kisah nyata seorang penyiar didong, Ibrahim Kadir, ketika dipenjara tahun 1965 di tanah Gayo, Aceh selama 22 hari. Akhirnya Ibrahim Kadir dilepaskan karena terjadi salah tangkap. Selama berada di penjara, tugas Ibrahim yaitu menutup kepala rekan-rekan sepenjara yang dibawa entah kemana, dan tak pernah kembali lagi. Ditembak mati, tanpa kejelasan pengadilannya. Mereka yang dipenjara juga tidak tahu kapan atau apakah mereka juga akan mendapat giliran untuk dieksekusi. Suasana menunggu menjadi tak jelas ujung pangkalnya. Dalam suasana demikian, Ibrahim Kadir masih sempat menciptakan puisi. Reaksi berlainan mucul pula dari mereka yang terpenjara itu, maupun dari wanita-wanita yang bekerja di dapur penjara. Persamaan antara film Puisi Tak Terkuburkan dengan pakasiah biola adalah sama-sama dengan menggunakan pengambilan gambar longtake, sedangkan perbedaannya terletak Puisi Tak Terkuburkan menggunakan satu ruangan, sedangkan 
pada Pakasiah Biola menggunakan satu komplek yang berisi penjara, kantor komandan, rumah komandan dan rumah biasa.

Film Biola Tak Berdawai karya Sutradara Sekar Ayu Asmara, diproduksi Kalyana S. Bira Film tahun 2003. Renjani (Ria Irawan) meninggalkan kota kelahirannya Jakarta, untuk mengubur masa lalu dan keinginannya untuk menjadi penari balet. Ia pindah ke Yogya dan mengabdikan hidupnya dengan merawat anak-anak tunadaksa yang tidak dikehendaki kelahirannya oleh orangtua mereka. Ia dibantu seorang dokter anak berusia 40 tahun, Mbak Wied (Jajang C Noer). Dewa (Dicky Lebrianto), 8th, menjadi anak kesayangan Renjani dan diperlakukan sebagai anak normal. Renjani terkejut melihat ekspresi Dewa, ketika ia iseng-iseng menari balet. Hal ini membuat Renjani membawanya ke resital biola. Di situ ia jumpa dengan Bhisma (Nicholas Saputra), mahasiswa musik berusia 23 tahun. Bhisma tertarik pada penampilan Renjani. Persahabatan pun terjalin. Begitu juga dengan Dewa yang juga bereaksi ketika Bhisma memainkan biola mengiringi Renjani menari. Film Biola Tak Berdawai dan film Pakasiah Biola sama-sama menggunakan biola sebagai alat penghubung untuk menarik perhatian seseorang, Biola Tak Berdawai menggunakan pendekatan biola untuk menarik respons seorang anak, sedangkan pada film Pakasiah Biola penggunaan biola untuk menyelamatkan diri dari eksekusi mati yang dihadapinya.

\section{METODE}

Proses pada penciptaan film ini nantinya akan menggunakan gaya realis film style, dimana pengkarya menciptakan sebuah film yang berasal dari sebuah cerita atau berdasarkan based on story, karya yang akan diciptakan nantinya akan menjadikan sebuah tantangan bagi pengkarya untuk mewujudkan sebuah cerita kedalam bentuk naskah yang nantinya akan digarap dalam bentuk film fiksi. Pengkarya nantinya mencoba mengekspresikan nilai yang terdapat pada cerita Babiola ke dalam bentuk karya film fiksi dengan menggunakan beberapa tahapan dari Andre Bazin yang meliputi: relative simple strories, pengkarya mencoba menghadirkan cerita Babiola kedalam bentuk film fiksi tanpa menghilangkan nilai yang terkandung dalamnya. Real location, pengkarya mencoba menghadirkan lokasi yang mendekati pada zaman kejadian, seperti penjara, kantor komandan, rumah komandan. Real setting, pengkarya akan menghadirkan properti yang menyerupai pada tahun 1965. Unprofessional actors, pengkarya akan menggunakan aktor amatir untuk tokoh utama, dan bekerjasama dengan para pemain yang memiliki karakter sesuai dengan peran yang ada dalam skenario, seperti komandan, istri komandan, beberapa tentara. Deep-focus, pengkarya akan menggunakan lensa $16 \mathrm{~mm}, 24 \mathrm{~mm}$, $35 \mathrm{~mm}$, dalam perekaman gambar pada saat produksi sehingga penonton dapat merasakan kejadian yang sedang berlangsung. Longtake, perekaman gambar serta pengambilan adegan dari awal hingga akhir adegan tanpa terputus. Minimize editing, pengkarya tidak menggunakan editing sebagai penyambungan gambar yang telah di kerjakan pada saat produksi, editing yang dilakukan hanya sebatas title, warna dan sycn audio (dialog) sehingga karya ini sesuai dengan yang diharapkan.

Penciptaan dalam sebuah karya seni, 
perlu dilakukan sebuah riset dan dan suara.

observasi data. Observasi perancangan karya seni film Pakasiah Biola ini dimulai dari mengamati serta menganalisa filmfilm yang telah dibuat sebelumnya, juga berkaitan dan berhubungan dengan gaya realis pada film Pakasiah Biola. Serta menonton video pertunjukan Babiola yang telah di pertunjukan oleh seniman Babiola, dan melakukan riset pustaka untuk memperkuat data tekstual kerja kreatif pada proses pembuatan film.

Mendapatkan cerita dari seorang dosen ISI Padangpanjang sekaligus peneliti tentang Babiola yang mengetahui cerita mitos tentang Munas salah satu orang yang panjang umur karna Babiola, dia berhasil selamat dari eksekusi mati yang dilakukan oleh tentara terhadap dirinya, dan sampai sekarang dia memiliki istri 9 orang, karna tuntutan ekonomi sekarang Munas hanya memiliki istri 4 orang, berbeda dengan seniman babiola yang lainnya sampai dulu sampai sekarang dia masih tinggal serumah bersama istrinya 12 orang.

Proses produksi film secara umum dilakukan dalam tiga tahap kerja produksi, yaitu praproduksi, produksi dan pasca produksi menurut William B. Adam (1977:2) preproduction, production dan postproduction. Dengan istilah yang berbeda David Bordwell, Kristina Thomson (2008. 20) mengatakan terdapat tiga fase dalam produksi film, yaitu preparation, shooting, assembly". Preproduction atau preparation merupakan proses persiapan sebelum shooting (perekaman suatu adegan) dilakukan. The preproduction process includes everything you must do berfore can begin shooting the picture. Production merupakan proses pengadeganan dan perekaman gambar
Berkaitan dengan capaian gaya film yang akan dihasilkan, pengkarya akan menitik beratkan pembahasan pada metode penyutradaraan dan pekerjaan spesifik yang menjadi cara dan langkah tercapainya film gaya realis. Layaknya sebagai sebuah gaya film ataupun seni yang lain, pengkarya akan memberikan perhatian khusus pada beberapa pekerjaan, tanpa mengabaikan pekerjaan lain.

1) Membuat konsep pendekatan penyutradaraan, terutama yang berkaitan dengan gaya film yang akan diciptakan.

2) Mendiplomasikan kerja dan mengarahkan tim dalam membuat konsep setiap divisi.

3) Menjaga proses persiapan shooting sesuai dengan konsep realis

4) Menjalankan proses shooting dan editing sesuai dengan konsep realis.

\section{PEMBAHASAN}

Nilai yang terkandung di dalam cerita tersebut seperti nilai religi, sejarah dan tradisi mistis. Nilai religi yang terdapat di dalam cerita tersebut adalah bagaimana seorang tukang rabab yang lolos dari eksekusi mati, memiliki ilmu pakasiah dan pitunang. Dalam ilmu Tasawuf di kenal dengan istilah syariat, tarekat, hakikat dan makrifat. Ilmu syariat yaitu hukum agama yang menetapkan peraturan hidup manusia, hubungan manusia dengan Allah Swt, hubungan manusia dengan manusia dan alam sekitar berdasarkan Alquran dan hadis (KBBI, 108:2016). Ilmu Tarekat adalah jalan menuju kebenaran (dalam tasawuf) (KBBI, 201:2016). Ilmu hakekat Wujud dari kebenaran yang dapat dilihat 
adalah kejujuran, keadilan cinta kasih. Pada tingkatan ini orang telah memahami makna ibadah yang dilakukan, misalnya "sholat mencegah kemunkaran", makna berzakat, makna berpuasa, makna berhaji. Ilmu ini juga disebut ilmu batin. Ilmu makrifat tingkat penyerahan diri kepada Tuhan, yang naik setingkat demi setingkat sehingga sampai ke tingkat keyakinan yang kuat (KBBI, 215:2016). Seperti yang dikatakan Soedarso SP, pelaku-pelaku seni tradisi mampu mencapai persentuhan yang menghadirkan sesuatu bersifat metafisik maupun mistis (2009:26). Berdasakan penjelasan di atas, pengkarya dapat menyimpulkan bahwasanya ketika kita beriman kepada Tuhan YME dengan kesungguhan dan sesuai dengan syariat islam maka Tuhan akan melindungi kita dari perbuatan maksiat, nilai tersebut menjadi daya tarik pengkarya dalam menciptakan karya film fiksi yang berjudul Pakasiah Biola.

Nilai sejarah yang dihadirkan pada cerita ini berlatar belakang pada zaman kelam (Gestapu/PKI) yang dialami bangsa Indonesia, yang terjadi di daerah Minangkabau. Sedangkan nilai tradisi mistis pada cerita ini menggambarkan kesenian tradisi musik Babiola di Minangkabau. Nilai ini nantinya menjadi ide bagi pengkarya untuk menuangkannya ke dalam sebuah skenario film Pakasiah Biola.

Pada konsep garapan karya film Pakasiah Biola, film ini berdasarkan pemikiran Bazin terdapat 7 hal yang menjadi elemen struktur film realis, yang meliputi: relative simple strories, real location, real setting unprofessional actors, deep-fosus, longtake, dan minimize editing. a. Relative simple stories. (Cerita yang relatif simpel)

Cerita yang akan dijadikan cerita film gaya realis dalam penciptaan karya ini adalah cerita tentang kejadian mistis yang dialami oleh seorang seniman seni tradisi Babiola sebagaimana yang sudah dipaparkan pada bagian latar belakang. Beberapa hal yang menjadi alasan pemilihan cerita serta menilai bahwa cerita tersebut merupakan cerita yang simpel antara lain :

1) Cerita Pakasiah Biola memiliki unsur naratif yang lengkap, ada peristiwa yang berisi konflik dialami oleh tokoh pada suatu tempat di suatu masa/era.

2) Materi dalam cerita Pakasiah Biola sangat potensial untuk dituturkan secara dramatik,

3) Lokasi, setting maupun peristiwa dapat diadakan atau dikondisikan, seperti satu komplek area dimana di dalam area tersebut terdapat penjara, rumah komandan, dan kantor komandan.

4) Karakter (tokoh) dalam peristiwa tersebut merupakan manusia real.

5) Peristiwa benar-benar pernah terjadi serta mengandung pesan-pesan humanis mengenai betapa rentannya nyawa manusia dalam konflikkonflik politik ataupun perang saudara.

Dalam rangka menjadikan peristiwa tersebut sebagai cerita yang layak dijadikan cerita film, serta sesuai dengan kebutuhan film gaya realis, akan dilakukan beberapa hal : 
a) Menganalisa unsur-unsur cerita, serta menambah dan atau mengurangi unsur tersebut sehingga memiliki unsur-unsur dramatik yang memadai sebagai cerita film. Adapun unsur-unsur dramatik tersebur berupa conflict, couriosity, suspence, surprise.

b) Menyusun unsur-unsur dramatik dalam bentuk plot poin sehingga dapat gambaran mengenai konstruksi dramatik film. Kostruksi dramatik tersebut harus sudah memperlihatkan bahwa penuturan cerita sudah membangkitkan dan mempertahankan rasa ingin tahu penonton.

c) Menyusun alur penuturan cerita dalam plot linier. Plot linier akan membantu menyampaikan realitas, karena dalam kehidupan sehari-hari setiap peristiwa selalu berjalan ke depan, berkembang seiring dengan perjalanan waktu. Alur cerita film yang berjalan sesuai dengan alur perjalanan waktu (selalu bergerak ke depan), akan mendukung proses pelaksanaan shooting, karena tidak harus memikirkan pendekatan-pendekatan visual seperti plot nonlinear.

d) Merancang penyampaian informasi (cerita) dalam bentuk adegan-adegan yang tidak sulit dilakukan oleh aktor, untuk memperkecil adanya pemecahan shot atau menyulitkan penerapan longtake. Rancang tersebut akan dituliskan pada scene direction dan scene dialog dalam skenario Pakasiah Biola.

e) Merancang dan menuliskan secara detail deskripsi lokasi, set, property, wardrobe dalam skenario. Sehingga menggambarkan lokasi, set, serta adegan yang realis.

Proses pengkaryaan cerita film Pakasiah Biola mengenai mistis dalam seni tradisi Pakasiah Babiola sudah sampai pada tahapan pengkaryaan treatment (treatment terlampir). Secara garis besar, dalam treatment sudah tercantum seluruh informasi yang membentuk cerita serta alur penuturan cerita. Cerita dituturkan melalui satu orang main character, lima (5) orang support character, dan 20 extras. Lokasi yang terdapat dalam cerita terdiri dari 2 lokasi, yaitu rumah penduduk dan kantor tentara (setara dengan koramil). Dalam lokasi tersebut terdapat 10 set, yang meliputi ruang depan rumah warga, ruang tahanan (sel), ruang kantor komandan tentara, depan rumah komandan tentara, ruang depan rumah komandan tentara, kamar komandan tentara, jalan antara rumah tentara dan kantor, lorong antara sel dan ruang komandan tentara, interior mobil truk, belakang kantor (tempat eksekusi tembak). Peristiwa dalam cerita berlangsung pada era tahun 1960 pada masa pergolakan PKI/Gestapu.

Proses kerja yang akan dilakukan adalah pengkaryaan skenario. Proses pengkaryaan skenario, selain mengacu pada penuturan cerita dramatic, juga mengacu pada konsep penciptaan film realis. Aspek detail, adegan-adegan simple, 
mendukung untuk proses longtake. Berdasarkan skenario tersebut akan dibuat disain produksi yang akan menjadi acuan kerja teknik produksi.

\section{b. Real Location (Lokasi yang real)}

Proses produksi akan dilaksanakan pada lokasi yang real. Sesuai yang telah disepakati pada saat hunting lokasi ketika praproduksi. film Pakasiah Biola akan dilaksanakan di lokasi perkantoran tentara, sebuah rumah warga, dan interior truk. Pada lokasi tersebut terdapat beberapa set, antara lain kantor komandan tentara, sel tahanan, rumah dinas tentara, kamar komandan tentara. Set pada rumah warga berupa set ruang tengah (ruang yang biasa dipergunakan masyarakat untuk menjamu tamu perhelatan). Semua lokasi dan set tersebut menggambarkan tahun 1960an.

\section{c. Real Setting (Set yang real)}

Setting sebagai tempat spesifik untuk pengadeganan akan dibangun sedemikian rupa sesuai dengan kaidahkaidah realitas. Realitas pertama adalah realitas fungsi ruang yang berkaitan dengan bentuk dan property, realitas yang kedua adalah realitas zaman yang juga berkaitan dengan bentuk property dan warna yang terdapat dalam set. Realitas yang ketiga adalah realitas pencahayaan. Selain itu, terdapat beberapa hal yang masih berkaitan erat dengan set, berupa wardrobe dan make up.

Pencahayaan yang real dapat diterjemahkan sebagai pencahayaan berdasarkan cahaya alam, berdasarkan sumber cahaya dan cara bagaimana cahaya tersebut menyinari objek. Pencahayaan seperti ini biasanya diterapkan dalam produksi dokumenter. Film fiksi, pencahayaan yang real bisa dilihat sebagai pencahayaan yang mengikuti kaidah-kaidah sumber cahaya dan membuat cahaya tambahan. Tapi, tidak bertentangan dengan logika sumber cahaya. Bagaimana membuat sebuah visual yang baik ketika sebuah adegan malam, dengan menggunakan pencahayaan lampu teplok tanpa bantuan cahaya tambahan. Tentunya visual yang baik untuk ditonton sulit untuk dicapai. Kemungkinan akan tercipta gambar yang under light, atau gambar yang noise. Dalam hal ini pembatasan tidak dilihat sebagai pengungkungan, akan tetapi sebagai sebuah stimulus atau tantangan untuk berkreativitas.

\section{d. Unprofessional actors (aktor amatir)}

Pemakaian aktor amatir dalam film Pakasiah Biola ini merupakan aktor yang mahir dalam memainkan Pakasiah Babiola tetapi tidak mahir dalam bermain film. Konsekwensi dari pemakaian aktor amatir yaitu berupa proses latihan baik mengenai metode karakterisasi maupun hal lain yang berhubungan dengan proses shooting. Kendala-kendala tersebut biasanya bisa diatasi pada saat proses casting dan reading, dengan cara memilih calon aktor yang memiliki kriteria tertentu dan kriteria tambahan sebagaimana tuntutan skenario. Kriteria tersebut bisa berupa tingkat kecerdasan, ketersediaan waktu untuk proses shooting, interest atau pengalaman keterlibatan dalam seni peran, profesi dalam kehidupan seharihari dan lain sebagainya.

Proses casting maupun persiapan terhadap aktor amatir akan membutuhkan waktu dan konsentrasi yang sangat besar, apabila dikaitkan dengan metode longtake. Kelancaran dan kerhasilan shooting 
dengan metode longtake sangat dalam mengikuti pergerakan objek, ditentukan oleh salah satunya melakukan perpindahan dari satu setting kemampuan aktor dalam berakting secara ke setting lain, sehingga menciptakan utuh, pada satu scene/setting/location komposisi gambar yang baik. Serta bisa atau bahkan dalam beberapa mempengaruhi kepada penonton yang bisa scene/setting/location tanpa terputus. merasakan suasana yang akan dihadirkan Proses latihan dengan capaian aktor dengan menggunakan lensa lebar.

harus benar-benar memahami cerita secara utuh, memahami dan mampu menjadi karakter secara total, dan mampu bekerja dalam konsep kerja tim.

\section{e. Deep-focus (pemotretan fokus terseleksi)}

Proses produksi film Pakasiah Babiola akan mempergunakan lensa dengan focal length $16 \mathrm{~mm}, 24 \mathrm{~mm}$, atau $35 \mathrm{~mm}$. lensa ini akan dipadukan dengan kamera dengan spesifikasi full HD ataupun $4 \mathrm{~K}$. Perpaduan antara kamera bersolusi tinggi dengan lensa tersebut menjadi support pada logika pecahayaan.

Deep-focus dilakukan untuk memberikan penekanan secara menyeluruh pada objek-objek yang terdapat pada setting. Deep focus ini akan memberi ruang bagi penonton untuk menerima informasi dari seluruh materi yang terdapat dalam sebuah gambar.

\section{f. Longtake}

Pada proses penciptaan film Pakasiah Biola, perekaman gambar dilakukan tanpa bantuan tripod. Untuk menjaga kestabilan gambar dan meringankan beban kameramen saat melakukan perekaman gambar, kameramen mempergunakan gimbal atau ronin. Selain untuk menciptakan kesan realis, uncamera mounting juga untuk membantu menciptakan gambar yang dinamis. Dengan tidak menggunakan tripod, maka pergerakan kamera pada saat shooting akan lebih leluasa, baik
Perpaduan antara longtake dengan uncamera mounting ini menuntut kamera operator maupun asisten (focus) memiliki daya tahan tubuh yang kuat serta konsentrasi yang tinggi. Supaya penonton dipaksa untuk fokus melihat kejadian demi kejadian.

\section{g. Minimized Editing (Minim editing)}

Pada film Pakasiah Biola akan menerapkan teknik pengambilan gambar dengan longtake. Dimana perekaman gambar dengan metode longtake, baik one scene one shot akan meminimalisir dramatisasi perasaan penonton dengan dampak-dampak yang ditimbulkan dari proses editing. Dalam dua scene adegan hanya akan ada satu penyambungan. Film yang akan diproduksi berdasarkan scene, akan dilakukan 13 kali proses penyambungan gambar. Penyambungan tersebut akan dilakukan dengan metode continuity editing.

\section{h. Format Warna Hitam Putih}

Format film terbagi menjadi dua kelompok, yaitu colours dan Black and white (BW). Format warna film pada awalnya hanya dipandang sebagai sebuah hal teknis, pilihan pada bagaimana warna unsur-unsur mise-en scene tampil dalam layar film, berwarna atau hitam putih.

Film Pakasiah Babiola akan diproduksi dan ditayangkan dalam format hitam putih. Format hitam putih digunakan untuk menekankan bahwa kejadian yang akan diceritakan dalam film 
adalah sesuatu yang sudah terjadi puluhan tahun yang lalu. Hal ini juga berfungsi untuk menjaga dampak/pandangan masyarakat terhadap seni tradisi Babiola pada saat ini. Kesan dan pesan yang akan disampaikan dengan format hitam putih adalah untuk menekankan informasi bahwa peristiwa dan segala materinya sudah lama terjadi. Ditampilkan dalam film merupakan kejadian masa lampau. Penekanan kejadian tersebut sangat penting untuk menjaga munculnya pandangan negatif terhadap para seniman Babiola yang ada pada masa sekarang.

Format film hitam putih mempunyai kekuatan untuk memperkuat kesan realitas zaman yang terkait dengan masa lalu. Hal tersebut terlihat dari pemilihan hitam putih ataupun sephia ketika menyampaikan bagian cerita yang bersifat flashback. Format hitam putih diterima sebagai suatu realitas yang terjadi pada masa lalu.

Perancangan film Pakasiah Biola ini antara lain, Pertama, sutradara menggunakan metode analisis cerita Pakasiah Babiola yang ada di daerah Pesisir Selatan. Analisis cerita adalah metode adopsi yang mengindentifikasi teks dalam hubungan latar belakang kontekstualnya. Metode analisis tekstual didefinisikan sebagai sebuah metode dimana pengkarya menggambarkan, menafsirkan, dan mengevaluasi karakteristik. Setelah itu dilanjutkan dengan bagian yang memuat aspek-aspek emosional seperti konflik atau ketegangan, dan pesan. Analisis tekstual dalam proses penciptaan ini, digunakan untuk menganalisis hubungan unsurunsur dalam carita berupa tema, alur, setting, latar cerita dan penokohan.

Kedua, pengkarya akan melakukan proses penciptaan film Pakasiah Biola. Proses ini, lebih difokuskan pada kerja directing. Adapun langkah kerja yang akan pengkarya lakukan adalah menerjemahkan skenario dalam bentuk visual, melakukan reading dan casting, menentukan mise en scene dan lokasi shooting, pengambilan gambar, dan proses editing.

Selain pemilihan cerita, aktor dan setting, realis film juga didukung dengan beberapa metode dan teknik, yang berkaitan dengan aspek sinematik. Prince (2007:438) mengatakan bahwa:

Bazin felt that the techniques best suited for realism were deep-focus cinematography (were a great distance separates sharply focused foreground and background objects) and long take (shot of long duration) in style that minimizes the importance of editing.

(Bazin merasa bahwa teknik yang paling cocok untuk realisme adalah sinematografi fokus-dalam (jarak yang sangat jauh memisahkan objek latar depan dan objek latar belakang) dan pengambilan panjang (bidikan dengan durasi lama) dalam gaya yang meminimalkan pentingnya pengeditan).

Berdasarkan pandangan Stephen Prince mengenai realisme film oleh Bazin maupun beberapa sineas lain yang dikupas oleh Prince, konsep film realis dapat dilihat seperti bagan berikut: 


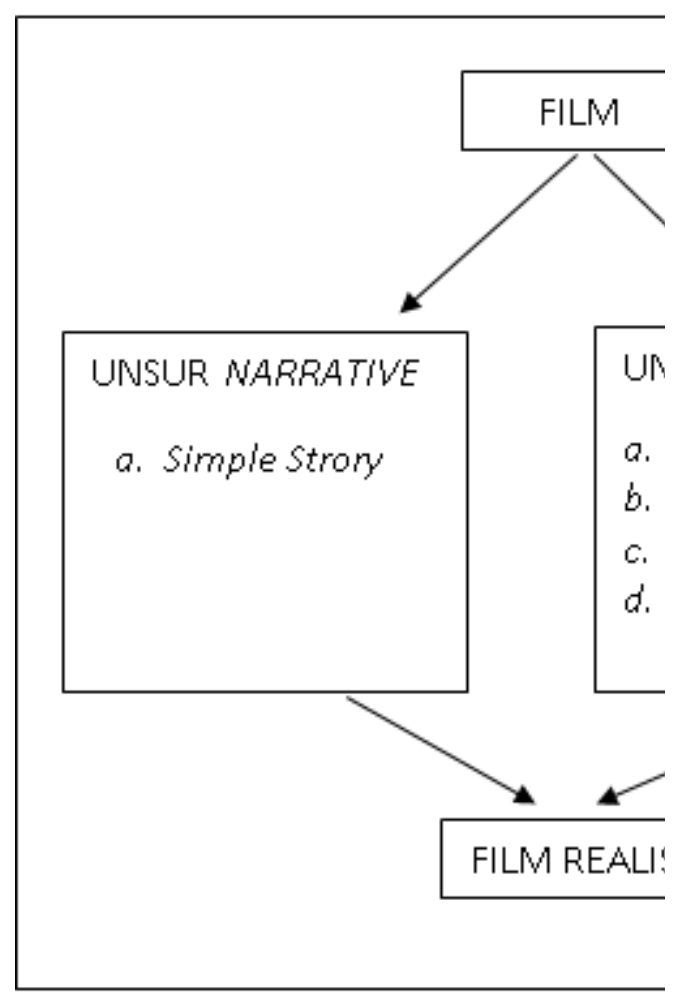

Pendekatan yang dilakukan dalam penciptaan Film Pakasiah Biola adalah realis film style dari pemikiran realisme dalam dunia perfilman mulai muncul sekitar tahun 1940-an, diusung oleh Andre Bazin yang merupakan sineas asal Prancis. Roberta E. Perason and Philip Simpson (2001:18-19) mengatakan :

The most influential of cinema is Andre Bazin, his appreciation of cinema is anchored in a film practice which knows sound, colour and a range of welladvance narrative systems. For Bazin, the cinema needs to recreate a new world, base on a realist depiction. Given its unparalleled ability to transport its viewer into a different world than his or her real one, cinema should aim at new world where we can go and exchange reality for another one.
(Yang paling berpengaruh dari sinema adalah Andre Bazin, apresiasinya terhadap sinema ditambatkan dalam praktik film yang mengenal suara, warna dan berbagai sistem narasi yang canggih. Bagi Bazin, bioskop perlu menciptakan kembali dunia baru, berdasarkan penggambaran realis. Karena kemampuannya yang tak tertandingi untuk mengangkut pemirsa ke dunia yang berbeda dari yang sebenarnya, bioskop harus mengarah ke dunia baru di mana kita bisa pergi dan bertukar kenyataan dengan yang lain).

Gagasan Andre Bazin tersebut kemudian melahirkan suatu teori film yang dikenal dengan realist film theory, yang berlandaskan pada ethical assumption about nature of reality. Bazin juga menawarkan elemen yang spesifik struktur film as the ones best suited for a realist style. Gaya/style film yang mengacu pada realist film theory diidentifikasi sebagai gaya realis (realist film style). Bazin's theory of realism has much to say about the ethical contract that obtains between filmmakers and viewers and about the extraordinary potential for cerocing emotion that filmmakers have at command. Dalam menjaga kontrak etika tersebut penganut realis berusaha mencari hubungan antara gambar yang ditampilkan dalam film dengan realitas dalam masyarakat atau kehidupan nyata. The theories of realism in the cinema look for point of correspondence between film image and social, psychological, and physical realities before the camera.

Sebagai sebuah gaya film, Bazin 
menjadikan penghadiran realitas yang ambigu, serta pemberian ruang bebas bagi respon penonton sebagai struktur film realis. Stephen Prince (2007:439) Bazin suggested that particular elements of film structure were more or less suited to representing the ambiguities of reality and giving spectators freedom of response. Oleh karena itu dalam keyakinan Bazin menurut Stephen Prince (2007:439) that filmmaker's should employ techniques thet honor and enhance the ambiguities of reality and give viewers room to develop their own interpretations an responses (bahwa pembuat film harus menggunakan teknikteknik yang menghormati dan meningkatkan ambiguitas realitas dan memberikan ruang bagi penonton untuk mengembangkan interpretasi mereka sendiri dalam memberikan tanggapan (terhadap apa yang mereka tonton). Pemberian atau penyediaan ruang bebas bagi penonton untuk menilai maupun merespon, tanpa mengarahkan penonton "secara paksa" pada suatu respon yang sama menggunakan teknik-teknik produksi (perekaman) maupun teknik editing, merupakan dasar dan capaian dari pemikiran realis film. Hal tersebut didasarkan Bazin pada pemikiran bahwa setiap penonton punya pengalaman dan realitas yang berbeda antara satu dengan yang lain. Pengalaman dan realitas tersebut akan melahirkan konsekwensi perbedaan respon terhadap apa yang mereka tonton. Film tidak bisa melepaskan atau mengabaikan begitu saja pengalaman dan realitas yang terjadi dalam kehidupan penonton.

Pemikiran dan kreativitas orangorang dalam dunia perfilman telah melahirkan beberapa kelompok klasifikasi tersebut ada yang berdasarkan format, ada yang berdasarkan teori, gaya dan ada yang berdasarkan genre.

\section{KESIMPULAN}

Berdasarkan hasil ulasan dalam pembahasan, maka analisis ini bisa disimpulkan bahwa cerita yang akan dijadikan cerita film gaya realis dalam penciptaan karya ini adalah cerita tentang kejadian mistis yang dialami oleh seorang seniman seni tradisi Babiola. Cerita Pakasiah Biola memiliki unsur naratif yang lengkap, ada peristiwa yang berisi konflik dialami oleh tokoh pada suatu tempat di suatu masa/era. Peristiwa benar-benar pernah terjadi serta mengandung pesan-pesan humanis mengenai betapa rentannya nyawa manusia dalam konflik-konflik politik ataupun perang saudara.

\section{DAFTAR PUSTAKA}

Adam B. William. 1997. Handbook of Motion Picture Production. New York : John Wiley \& Sons

E. Pearson, Roberta and Simpson. Philip (2001) Critical Dictionary of Film and Television Theory. New York : Rouledge.

Bordwell, David \& Thompson, Kristin. 2008. Fim Art: An Introduction Eight Edition. New York: Hinger Education.

KBBI (Kamus Besar Bahasa Indonesia)

SP, Soedarso. Eksistensi dan Penciptaan Seni. Yogyakarta : ISI Yogyakarta Press.

Prince, Stephen. 2007. Movies And Meaning ; An Introduction to Film. Fourth Edition. Boston : Pearson. 